\title{
UNDERSTANDING WOMEN EMPOWERMENT IN RURAL COMMUNITIES: A CASE STUDY OF SAHIWAL DISTRICT, PUNJAB PAKISTAN
}

\author{
Abdullah Ijaz ${ }^{1}$, Adnan Ahmad Dogar ${ }^{2 *}$, Ikram Shah ${ }^{3}$, Mohammad Saeed Lodhi ${ }^{4}$, Shakirullah Dawar ${ }^{5}$ \\ ${ }^{1}$ Queen Mary University of London, United Kingdom; ${ }^{2 *, 3,4,5}$ COMSATS University Islamabad, Abbottabad Campus, \\ Pakistan. \\ Email: ${ }^{1}$ abdullahijazabdullah@ hotmail.com, ${ }^{2 *}$ adnandogar@cuiatd.edu.pk, ${ }^{3}$ ikramshah@ @ cuiatd.edu.pk, \\ ${ }^{4}$ saeedlodhi@cuiatd.edu.pk, ${ }^{5}$ shakirdawar@cuidatd.edu.pk
}

Article History: Received on $11^{\text {th }}$ May 2021, Revised on $18^{\text {th }}$ May 2021, Published on $27^{\text {th }}$ May 2021

\begin{abstract}
Purpose of the study: The purpose of the study was to analyze the socio-cultural constraints that affect different dimensions of women empowerment in rural areas of Punjab province. Political participation and self-esteem were taken as dominant characteristics of women empowerment among lots of variables that collectively define women empowerment.

Methodology: A mixed-method approach was used to study different dimensions of women empowerment. A multi-stage random sampling technique was used to collect the data from 85 respondents excluding widows and divorced women. Two focus group discussions were conducted, one in each village to further understand the phenomenon or empowerment and constraints faced by women. The data got analyzed by using tables and graphs made in MS Excel.
\end{abstract}

Main findings: Findings of the study indicate that although cultural constraints hinder the process of women empowerment a great deal, a husband's education along with a woman's education plays a significant role in women empowerment. Results showed that if the husband is more educated, women are more empowered politically and have higher self-esteem.

Application of the study: The significant contribution of a single factor in overall women empowerment is very interesting and needs further in-depth studies on different locations. The results can contribute to policy formulation for women empowerment on a larger scale.

Keywords: Women Empowerment, Rural Communities, Sahiwal, Education, Socio-cultural.

\section{INTRODUCTION}

There is a plethora of research on women empowerment, and it has surely become a familiar term in the development literature. However, a comprehensive definition of the word "empowerment" remains elusive. This difficulty primarily emerges due to a latent phenomenon of empowerment that is not easily observable. Several scholars have attempted to examine the existing body of knowledge on women's empowerment and its link with international development (Cornwall \& Anyidoho, 2010; Kabeer, 1999). The empowerment of women is detrimental to achieving the full potential of human resources available to a country. The role of women in household decision-making and on a societal level can bring about positive social change and enhance the success of various development programs (O’Donnell et al., 2021).

In this study, we aim to understand women empowerment through two dimensions i.e., political participation and selfesteem. Understanding these dimensions is important as it may help us evaluate how women conceptualize empowerment in these dimensions and how crucial is to develop policy interventions that aim to empower women in different areas.

Women empowerment is a multi-dimensional process having socio-cultural, legal, familial, political, and psychological dimensions (Mahmud et al., 2012). In the past few decades, most of the policy interventions regarding women empowerment stressed improving the economic wellbeing of women, considering it to be the most effective way of empowering women. It has been contested that if economic empowerment is achieved, all other empowerment dimensions will follow accordingly (Bradshaw, 2013; Malhotra \& Schuler, 2005). However, there is a growing body of knowledge arguing that economic empowerment might be necessary for many ways, but it is not a panacea for the overall empowerment of women (Denney, 2015). Researchers focused on understanding the relationship between women empowerment and its impact on maternal and child health. It is widely acknowledged that the negative impact of health on overall welfare is much higher for girls than for boys (Friedman \& Schady, 2009). The fact that women in developing countries now have better control over their fertility and access to healthcare doesn't ensure that they have become more empowered (James-Hawkins et al., 2018; Lépine \& Strobl, 2013; Malhotra et al., 2014). Despite all research efforts in understanding women empowerment and determining empowerment indicators, the process of empowerment is still widely unknown due to its multi-dimensional context (Mahmud et al., 2012). In this study, we aim to understand women's empowerment through two dimensions i.e., political participation and self-esteem. Understanding these dimensions is important as it may help us evaluate how women conceptualize empowerment and how crucial it is to develop policy interventions that aim to empower women in different areas. 


\section{LITERATURE REVIEW}

\section{Concept of Women Empowerment}

Empowerment is the process through which the powerless gain control over their life choices and decision-making (Gupta \& Yesudian, 2006). Thus, having the liberty of making one's life choices represents a greater exercise of power and empowerment. The idea of empowerment applies to both sexes; however, it pertains to more value for women because they are prone to subjugation in terms of class and other social distinctions. Also, in the context of household and intra-familial relationships, women are more subjected to powerlessness (Malhotra \& Schuler, 2005). Keeping in mind, the complex nature of the empowerment phenomenon, it can be defined as having more life choices, gain control over one's life, and living a fulfilled life one wishes to live regardless of any gender discrimination. Gender inequality is based on social stratification and different roles and responsibilities are usually designated with a different gender. The women's status and degree of empowerment are generally determined through gender roles, identities, and dynamics are conceived at a family level and society level (Gupta \& Yesudian, 2006).

\section{Role of “Agency" in determining Empowerment}

Agency is one of the most crucial components of women's empowerment. It is said to be effective when a woman can make a choice and act according to her self-interests. It denotes a change in perception about the ability of women to consider themselves an important part of the decision-making process (Buvinic et al., 2020; Kabeer, 1999). Another important element is to determine the access and control over resources (social, material, and financial) that are available to a woman in different domains of family and community. The initial conditions which are available to women pave the path for women's empowerment. They can either hinder or support women's agency (Mahmud et al., 2012). Broader characteristics such as marriage, family wealth, caste, and influential family do provide various choices and play an important role in framing the women empowerment process (Bandiera et al., 2020).

As the empowerment process is not very simple and observable, it can only be measured using some indicators. The initial resources that are available to women i.e., education, paid work, or media exposure do not necessarily mean that they will translate into the agency. Economic theory predicts that an increased level of education is directly related to increased earnings (Mustafa et al., 2017). Education is the investment that turns unskilled labor into skilled labor and improves the rate of returns considerably in the labor market (Hirji, 2021; Malhotra \& Schuler, 2005). However, this trend is not uniform across all the countries owing to varying cultural and political dynamics (Caldwell, 2007).

\section{Women Empowerment: A multi-dimensional concept}

Women empowerment is multi-dimensional. It is pertinent to understand that the empowerment process can be dynamic and exists across different dimensions i.e., social, political, economic, and psychological. The underlying pathways through which resources are transforming into the agency can revolve around different dimensions i.e. cognitive, perceptual, material, and relational (Chen \& Mahmud, 1995). There exists a wide range of statistical evidence that suggests lower political participation of women as compared to men (Roy \& Tisdell, 2002). Literature also reveals the political participation of women in their stereotyped roles. Women are placed in the low ranks of political structure where they cannot exercise authority to affect their wellbeing (Furuta \& Salway, 2006). To ensure the political participation of women, it is of utmost importance to introduce gender equality and equity in the provision of education (Dineen \& Le, 2015). The role of knowledge is significant not only in preparing them for the labor market but also in understanding and challenging their social world (Stromquist, 2015).

According to United Nations Women's Annual report 2018-19, one way to ensure women's empowerment and improvement of their economic and social status is to establish mechanisms for women's equal participation and equitable representation at all levels of the political sphere (UN Women, 2018-2019). The women empowerment literature on political participation and self-esteem is relatively scarce and in the case of Pakistan, there is a dearth of research on these aspects of empowerment (Khan et al., 2021). South Asia is a part of the world that showed a slow pace in experiencing demographic changes. Sharp inequalities exist among men and women in the region (Jayachandran, 2015). Several studies provided theoretical interpretations claiming increased gender inequalities are associated with social, cultural, and demographic norms of an area (Caldwell, 2007). In rural areas of the developing world, women play a critical role in the management of household as well as active participation in agricultural production (Duflo, 2012). Regardless, of their economic and social contributions, national development policies and programs tend to ignore the central role of women as an agent of economic and social development (Solomon \& Adekoya, 2006).

\section{The rationale of the study}

Rural women, in most developing countries, lack access to education, basic healthcare facilities, and financial services which result in quite low decision-making power as compared to their male counterparts. Pakistan is no exception where women 
are deprived of basic economic and social rights (Javed, 2021). Their contribution to society has not been valued on equal grounds with men. Despite many coordinated efforts of central and provincial governments, the social status of women could not be uplifted to the desired level. The study intends to provide an insight into the current state of affairs and viewing empowerment through the prism of self-esteem and political participation.

\section{THE AIM AND OBJECTIVES OF THE STUDY}

The study aimed to investigate the perceived definition of empowerment for rural women. Further, analyze the association between socioeconomic factors and two dimensions of women empowerment i.e., self-esteem and political participation. The specific objective was:

1) To analyze how women in rural settings perceive empowerment and its determinants.

2) To investigate the causal association between determinants of women empowerment and its dimensions (self-esteem and political participation).

\section{METHODOLOGY}

\section{Measures and Procedures}

As discussed above, empowerment is a complex phenomenon and may mean differently for different people depending upon his/her education, gender, exposure, or socio-cultural backgrounds. Jejeebhoy (2002) provided a framework for socioeconomic variables that could be used to understand the impact of such determinants on different dimensions of empowerment. Adopted from his work, the study used age, economic status specified by household wealth, social status indicated by the number of schooling years, \& media exposure as important determining factors whereas women empowerment was gauged through two dimensions namely self-esteem and political participation.

The dimension of self-esteem incorporates the psychological factors which are pre-requisite in determining the status of the women. In the self-esteem dimension, there are two different angles to be judged upon. First is the decision-making of the women as to which decisions she considers important to have her input. The other one includes scenarios under which they consider the beating of a husband justified. If women consider men's right to beat their wives, it indicates lower self-esteem among women. On the decision-making side, 9 scenarios were asked to indicate their choice of option. The first scenario included buying furniture and women have been asked whether they consider themselves to have a say on buying furniture for the house. The options presented were "Yes", "No" \& "Doesn't Know." Similarly, other scenarios included buying furniture, spending family savings, taking a loan, visiting a doctor for herself, working outside the home, visiting her father's home, having more children \& use family planning. The other side of self-esteem included scenarios where women considered beating as justified or not. There were six scenarios presented in front of the women and they were asked whether they considered beating justified in any of these circumstances. These included if she burns the food, neglects her children, talks to other men, argues with her husband, wastes her husband money, and goes out without telling her husband. The answer options presented to these women were "Yes", "No" \& "Doesn't Know."

To measure political participation among rural women of the Sahiwal district, they were asked questions regarding their political behavior. Six scenarios were taken which are critical in measuring the dimension of political participation. Firstly, they were asked about whether they cast vote in the elections of 2013. The other scenarios included: 1) participated in a campaign, 2) membership of any political party, 3) participated in protests, 4) formed an association, \& 5) became a member of any association. The answers were recorded in "Yes" or "No", for yes, the answer was coded "1" and for no, it was coded as " $0 . "$

\section{Sampling Technique and Sample Size}

A multi-stage random sampling technique was used for data collection as the study needed to gather data from a large population with limited time and cost. In this technique, sampling is done through two or more stages. The nature and size of sampling units change from time to time and the final stage presents the required sampling units (unit of analysis). The first stage of the multi-stage sampling divides the population into different units, which are also called primary sampling units (PSU). In the second stage, desired units are selected from the PSUs. This goes on until the last stage of sampling and the sample is selected randomly throughout the process. Sahiwal District of rural Punjab was chosen from all the districts of Punjab at random for the study. In district Sahiwal, two towns were selected at random to study the population. In the third stage of sampling, union councils of the towns were shortlisted at random. In the fourth stage, villages were chosen from the union councils. In the last stage of the process, 45 households from one (986/R) and 40 households from the second village (Harappa) were selected excluding widows and divorced women. The slight differentiation among the population of study from two different villages is due to varying population sizes of the respective villages.

Focus group discussions (FGDs) were used to have a deep insight into the phenomenon from all perspectives by generating 
meaningful debate. Two FGDs were conducted in the study area where the nomination method was used for the selection of participants through key informants. First FGD was conducted in Chak No. 986/R in Sahiwal District with 10 married women as participants. The second FGD was conducted in Harrapa Town where 12 married women were selected for the study. Participants included housewives, field workers, women farmers \& teachers. Together the respondents of the survey and FGDs consisted of 107 respondents.

\section{Data Collection and Analysis}

A team of 5 dedicated and committed enumerators were selected from the department of sociology, Government College University Faisalabad, Sahiwal Campus. Two days of training of the enumerators were conducted at the university where the questionnaire was explained in detail and necessary training was provided to develop rapport with the respondents while conducting the survey. Women were encouraged to share and discuss their perceptions regarding empowerment during the surveys. Their experiences, beliefs, and understanding of the different dimensions of empowerment and constraints in achieving them were recorded. Quantitative data was analyzed through tables and graphs made in MS Excel. Qualitative data collected through questionnaires and FGDs were organized into themes and sub-themes for qualitative analysis.

\section{RESULTS AND DISCUSSIONS}

The mean age of all respondents came out to be 35 years which is quite mature age for women. The maximum age for women was 50 years and the minimum came out to be 19 years. The average education of all respondents was 9.5 years. In most cases, rural women do not watch media for long hours due to household chores and duties. The average income of the rural household is also relatively good. This indicates the strong economic background of most of the women. Average years in marriage came out to be 14 years which indicates that most of the women get married at an early age. The focus of the study was to analyze the constraints rural women face in terms of empowerment and their status. Most of the questions were asked according to the need of the situation and condition. Many of the messages received were in the Urdu language and some of them in Punjabi.

\section{Empowerment, as perceived by rural women}

It is important to know the perception of women about women empowerment and what factors they consider are important in enhancing their status and giving them more control over their lives. Education is one of the most valuable assets in one's life. It can provide access to many other opportunities. For women, education is considered to create a positive spillover effect on economic conditions, civic sense, health and nutrition, and political participation. It can go beyond the individuals to the community level (Center of Gender Policy Studies, 2016).

Rehman et al. (2020) identified age, education, and income levels as the main components of women empowerment. Other important factors include marital status, education of the husband, access to microfinance, and several sons alive (Khan \& Noreen, 2012). To investigate women's empowerment, all these indicators were taken into consideration to see how they are perceived by women in terms of cultivating women empowerment. Both questionnaires and interviews explored these socioeconomic characteristics that play a conducive role in the empowerment process.

Survey results indicate that women are quite aware of their rights to education and its fundamental role in promoting empowerment. Around $70 \%$ of the respondents stressed the importance of education in their lives and its role in granting them more decision-making power at the household level. One of the mature women, who got educated till $10^{\text {th }}$ grade said:

Women empowerment is all about education and awareness. A woman who is knowledgeable enough to know her rights is truly empowered. In our village, most of the women are not aware of their rights. However, education is a game-changer. I have seen women who get educated tend to be more empowered and they take a decision on their own.

Likewise, an educated woman who is a professional teacher shared the same views:

For the empowerment, it is essential to have a separate identity of a woman from her in-laws. She needs mobility and decision-making power to be able to take control of her life. Education played an essential role in my life.

Another relatively younger however uneducated rural woman said:

To me, women empowerment is about having a separate house and be able to take decisions of my household i.e., buying new stuff. If I cannot have a say at home... how can I be empowered?

These views strongly represent rural women's conditions and what they truly considered empowerment. According to most women, there is a dire need for better educational facilities and awareness to uplift their status. Some of the women also reflected their views regarding treatment from their husbands. A middle-aged woman with secondary education said: 
To be empowered, it is important to get good treatment/behavior from husbands. An understanding partner can boost your confidence to achieve more in life. I feel empowered because my husband understands me, and we take all the decisions together.

\section{Self-Esteem}

Women empowerment can be gauged in various forms depending upon the cultural context of the region and socio-economic variables. As the data has been collected from the Sahiwal districts of Punjab province, it gives interesting insights into the views and perceptions of women in rural Punjab. There were 5 dimensions of women empowerment selected for the study as described above in the theoretical framework. In the dimension of self-esteem, $\%$ responses were recorded from the women regarding their perception of decision making whether they should be involved in the household decision making and whether they considered beating as justified or not.

With the help of literature and pretesting, we selected 10 scenarios under which the decision-making power of rural women has been evaluated. Out of all the scenarios, three scenarios came out to be the most significant ones. They included whether women have decision-making power in buying furniture for the home, buying livestock, spending family savings on her and inmates, taking a loan, visiting doctor for self, working outside the home, visiting father's home, having more children, use of family planning and voting. Spending family savings gives an economic right to women and she acknowledges that. Most of the women considered visiting their father's house as her right and they do not want permission for it. It should be solely their decision whether to visit their father's house or not. However, it is also important to note that most of the women have their father's house in the same village. The results could have been different if their father's house would have been indifferent villages. The study indicated that $73 \%$ of the women said it is important to include them in the decisions to buy furniture for the home. The two other factors were highly important for women to be included in decision-making. The reason for buying furniture comes more often because of women's nature and they perceive themselves as the owner of the house; it seems extremely important for her to be included in all the household decisions. Under the dimension of domestic violence of self-esteem, women were introduced to different scenarios under which they considered beating from their husbands was justified. Results showed that in different situations women respond differently. For example, when they were asked whether they considered beating justified when she talks to other men, around $56 \%$ of women said yes. It shows that quite a high percentage of women considered beating as justified in this case. However, $4 \%$ of women said that they do not know whether beating would be justified in this case or not. In another scenario presented where they were asked whether they considered beating by their husband justified if they go outside of the home without telling them. Only $41 \%$ of total respondents believed that beating would be justified in that case. $49 \%$ of women said beating would not be justified in such a case. This is mainly due to what if an emergency comes and she must leave the house without notifying or taking permission from the husband. Women were asked whether beating by the husband is justified if she wastes his money, $45 \%$ of women considered beating justified in such scenario. However, a small percentage of the women considered beating justified in these situations. The high percentage of women who considered beating is justified was under the scenario if women argue with her husband. A very small percentage of around $26 \%$ considered beating as justified if women burn the food. This is particularly true because, in rural culture, men or husbands are the authority in the house. If women argue in front of them, that would be not appropriate. Interestingly, rural women weigh beating justified when she argues than talking to other men. While in South Asian countries, talking to other men is also regarded as taboo for married women however, the findings of this study showed that arguing with the husband is much more important than any other dimension. Almost 56\% of the women out of the research sample said beating is justified when they talk to other men. Apart from these scenarios, rural women considered beating as justified when she wastes her husband's money. This is due to males is the only earning member of the family and women are there to take care of the family in meeting their financial obligations and efficiently spending money. If money gets waste on the part of women, they consider beating justified in this scenario.

Table 1: Scenarios when Respondents Consider Domestic Violence (Physical Abuse) as a Justified Act

\begin{tabular}{lllll}
\hline S. No. & Abuse is justified when she & Yes $(\%)$ & No $(\%)$ & Do not Know (\%) \\
\hline i. & Talks to other men & 48 & 34 & 3 \\
\hline ii. & Goes out without telling her husband & 35 & 42 & 8 \\
\hline iii. & Wastes her husband money & 38 & 28 & 19 \\
\hline iv. & Argues with her husband & 63 & 13 & 9 \\
\hline v. & Neglects the children & 44 & 20 & 21 \\
\hline vi. & Burns the food & 22 & 38 & 25 \\
\hline
\end{tabular}

Source: Based on data collected during the survey

The figure explains the response from the women regarding beating as justified or not. $18 \%$ of women considered beating as not justified activity regardless of any of the scenarios. To them, beating should be strongly condemned and husbands have no authority to beat their wives under any circumstances. $29 \%$ of the women considered beating as justified under one 
scenario. Almost $21 \%$ of the respondents considered beating as justified in two specific scenarios. However, in all six scenarios, only $6 \%$ of the women considered beating as justified.

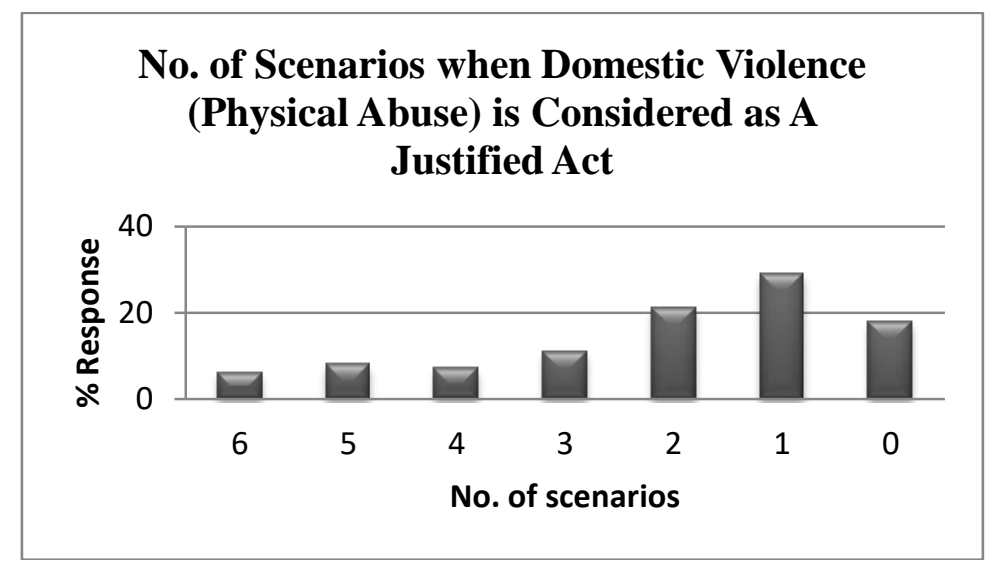

Figure 1: No. of Scenarios under which beating is justified

Source: Based on data collected during the survey

Different socio-economic factors play an important role in determining women's behavior with beating justification. As indicated in the literature review, education plays an important role in empowering the status of women. Hence, we carried our data analysis to check whether education plays any role in creating awareness among married women about beating; whether it is justified or not in different scenarios. As the results came out, we got to know that Education does play a role and most of the women who were educated said beating is not justified in any of the circumstances. However, as the education level goes down, women's perception and justification about beating by the husband increases. This indicates that educated women know more about their rights and she is in a better position to negotiate her rights in comparison with the women who are less educated. It is important to note down that in FGDs women usually admitted that beating is not a justified act. However, Islam only allows beating in severe cases. Our survey results comprehend this finding further with these results. Men usually take advantage of misinterpretation of religious values and assure women that beating them is justified both in religious and cultural terms. When women were asked about society's perception regarding men's right to beat their wives, mostly (38\%) were of the view that society does not accept men's right to beat. This was an interesting finding as it is a popular belief in our culture that men have authority over women, and they can beat their wives. The reasons which allowed women to think it is fine if men beat under certain circumstances goes back to their childhood if they had seen their fathers beat their mothers or another pertinent reason for this justification is a familiar experience of fellow women which let them think it is fine for men to beat their wives under certain situations. In the FGDs, most of the women said that society doesn't accept men's right to beating which is mainly due to awareness on media.

Table 2: Impact of Various Socio-cultural Factors on Political Participation

\begin{tabular}{|c|c|c|c|}
\hline Sr. No. & Covariates and categories & $\begin{array}{c}\text { Involvement in Political } \\
\text { Participation (Max. } 6 \text { scenarios) }\end{array}$ & $\begin{array}{c}\text { Self- } \\
\text { esteem }\end{array}$ \\
\hline \multirow[t]{4}{*}{ i. } & Age of Respondent (Years) & & \\
\hline & $<25$ & (1.8) & -0.01 \\
\hline & $25-35$ & (2.1) & \\
\hline & $\geq 35$ & (1.6) & \\
\hline \multirow[t]{4}{*}{ ii. } & $\begin{array}{l}\text { Average Monthly Income of the } \\
\text { Household (Rs. PKR) }\end{array}$ & & \\
\hline & $>35,000$ & $(2.4)$ & -0.38 \\
\hline & $20,000-35,000$ & $(2.1)$ & \\
\hline & $<20,000$ & $(1.5)$ & \\
\hline \multirow[t]{4}{*}{ iii. } & $\begin{array}{l}\text { Education of the Respondent } \\
\text { (No. of Years) }\end{array}$ & & \\
\hline & $<5$ & $(1.8)$ & 0.47 \\
\hline & $5-10$ & $(2.4)$ & \\
\hline & $\geq 10$ & $(2.7)$ & \\
\hline
\end{tabular}




\begin{tabular}{llll}
\hline & $<2$ & $(1.6)$ & 0.15 \\
\cline { 2 - 4 } & $2-4$ & $(1.7)$ & \\
\cline { 2 - 4 } & $\geq 4$ & $(1.5)$ & 0.65 \\
\hline v. & Husband's Education (Years) & $(1.6)$ & \\
\cline { 2 - 4 } & $<5$ & $(2.1)$ & $(2.6)$ \\
\cline { 2 - 4 } & $5-10$ & $\geq 10$ & \\
\cline { 2 - 4 } & \multicolumn{2}{l}{ Values in parenthesis show mean values of six scenarios each scenario with a score 1 } \\
\hline
\end{tabular}

Source: Based on data collected during the survey

Table 2 represents the impact of different determinants of women empowerment. It shows the relationship between these factors and women empowerment. As we analyzed different constraints which hinder the process of empowerment, we will also consider socio-cultural factors which can have an impact on these dimensions of empowerment. As shown in the table above, the mean scores regarding six scenarios of beating justification, women of different ages responded differently. This shows a weak relationship of age with the self-esteem of women. However, results show that there is a weak relationship between income per month and self-esteem of the women. The number of years of schooling has a positive impact on the self-esteem of women. This means that as a woman gets educated, her self-esteem also enhances with time. Access to media also must play a role in enhancing the self-esteem of women as indicated in the table above. However, the husband's education plays a major role and it is quite relevant and compliments women's education in the case of the self-esteem dimension of empowerment.

\section{Political Participation}

In the women's empowerment dimension of political participation, many disappointing results have appeared. In the six scenarios presented below, only one situation under which women need to cast their votes has been recorded high. However, only $49 \%$ of women cast votes in the election of the Year 2018. Apart from casting votes, only a few women participated in the campaign activity which again shows lower political participation among women. Only $4 \%$ of women out of the sample study formed an association. Few of them have membership in any political party. Hence it indicates lower political participation among women. Similarly, only $11 \%$ of the women became a member of any political party. This means that their representation in the political arena is quite lower. This is mainly due to socio-cultural constraints which do not allow women to actively participate in political activities.

Table 3: Frequency Distribution and percentages of women in political participation

\begin{tabular}{clcc}
\hline S. No. & $\begin{array}{l}\text { Nature of Political Participation During Last } \\
\text { General Elections }\end{array}$ & Yes & No \\
\hline i. & Became member of any association & $4(0.05)$ & $81(0.95)$ \\
\hline ii. & Formed an association & $3(0.04)$ & $82(0.96)$ \\
\hline iii. & Participated in protests & $8(0.09)$ & $77(0.91)$ \\
\hline iv. & Membership of any political party & $9(0.11)$ & $76(0.89)$ \\
\hline v. & Participated in political campaign & $12(0.14)$ & $73(0.86)$ \\
\hline vi. & Voted in a ballot & $42(0.49)$ & $43(0.51)$ \\
\hline
\end{tabular}

(Values in parentheses represent percentages)

\section{Source: Based on data collected during the survey}

Political participation is instrumental in bringing change regarding women's status and decision-making. Though, it assigns authority to a woman to make decisions on behalf of all women of her local area. However, male dominance hinders women's active involvement in politics. Also, women usually perform household duties e.g., looking after children, performing household chores, and taking care of the needs of family members. These social constraints impede the process of women participating in politics. Lesser political participation shown by women in this study indicates the socio-cultural boundaries that restrict women from their active participation in politics even though this participation can be instrumental in bringing positive change in their overall status. However, the survey results show quite low participation of women in terms of voting as well which is a duty of every citizen of any democratic country.

Table 4: Impact of Various Socio-cultural Factors on Political Participation

\begin{tabular}{llcc}
\hline Sr. No. & Covariates and categories & $\begin{array}{c}\text { Involvement in Political } \\
\text { Participation (Max. 6 scenarios) }\end{array}$ & $\begin{array}{c}\text { Self- } \\
\text { esteem }\end{array}$ \\
\hline i. & Age of Respondent (Years) & & \\
\hline
\end{tabular}




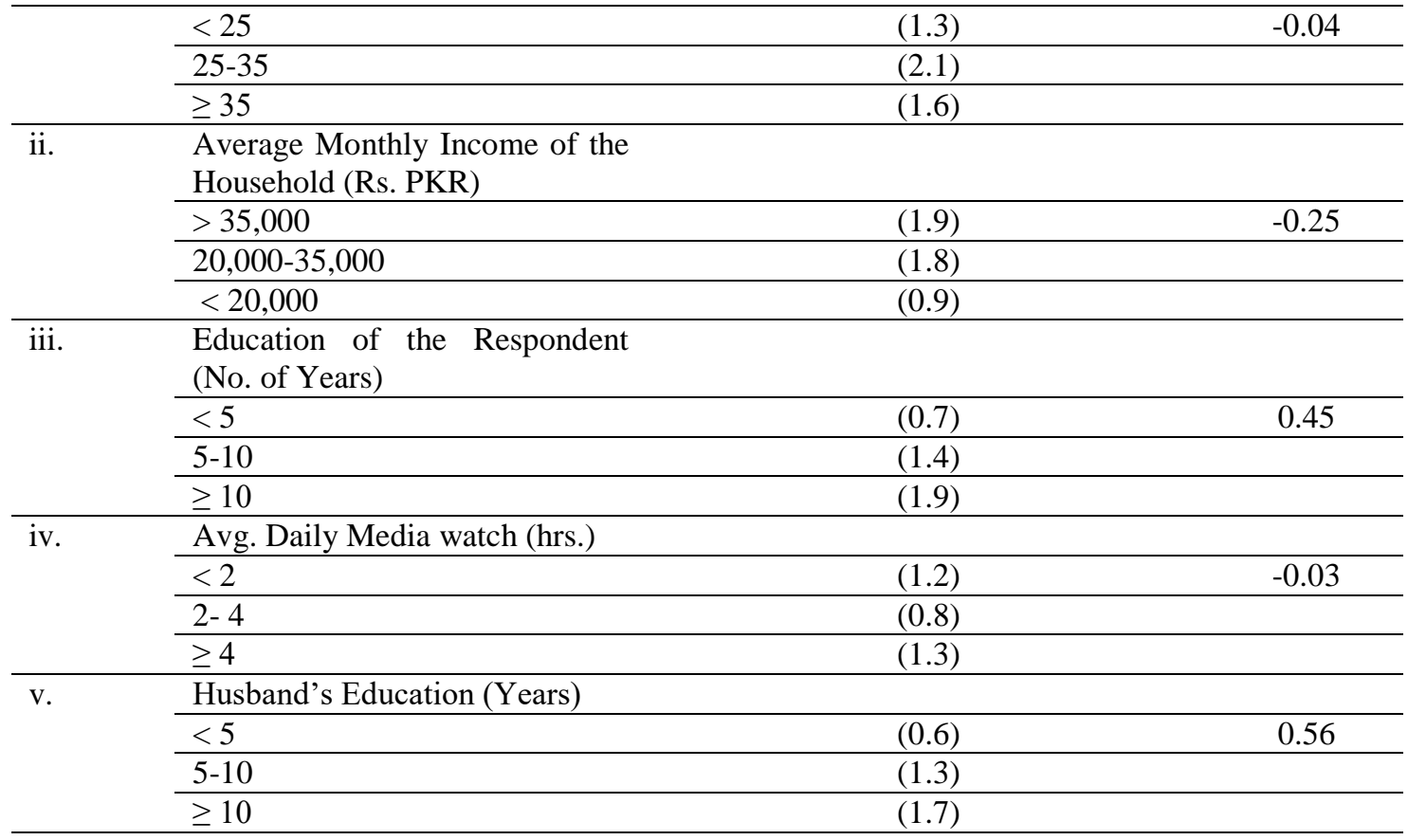

(Values in parenthesis show mean values of six scenarios with each scenario score 1)

Source: Based on data collected during the survey

Table 4 shows the nonlinear relationship between age and political participation. It shows variables are not positively correlated to each other and which are negatively correlated with one another. If the correlation coefficient is negative, it shows the two variables can have a weaker and negative relationship. In this dimension, different factors of women empowerment have been selected and their correlation with the political participation of women has been analyzed. Some of the findings include women's education's positive correlation with the dimension of political participation. It is 0.45 positively correlated which means that if women's education improves, their political participation also improves. On contrary, the role of media in considering the active participation of women in politics shows no positive relation. It is positively correlated.

Family income also shows a weak correlation with the overall political participation score of the women. It shows that the family income or economic power of women does not necessarily increase their participation in politics. However, a greater number of years of a husband's education is positively correlated with the active political participation of women. As women who have educated husbands to get more political knowledge through discussions with their husbands and their inclusion on voting ballot papers.

\section{CONCLUSION}

This study has unveiled the different perspectives of women regarding empowerment in socio-cultural, economic, psychological, and political dimensions. Also, socio-cultural constraints have been discussed in the study. It is evident from the results that all these dimensions influence the status of women or their empowerment. However, it is also important to understand that empowerment may mean differently for different women belonging to their socio-cultural context. Education turned out to be the most striking factor in uplifting the status of women and illiteracy is one of the biggest constraints which hamper the process of empowerment. According to women's perception about empowerment, they considered education as the most important determinant. As women are educated, they feel less trapped in cultural dogmas and can take decisions on their own. Also, this study revealed an important discovery that has not been discussed in detail before. Husband's education compliment women's empowerment as it is one of the primary sources of boosting women's confidence and granting them rights. If a husband is educated, he usually shows support for her wife in all endeavors. He also understands the needs and rights of women and attempts not to create hindrances in her goals. Moreover, educated, and literate men discourage domestic violence and abuse of women because of their exposure and soft worldview. Eventually, the study concluded that self-esteem and a husband's education are important factors that can enhance the status of the women. Along with this, a greater number of years of husband's education is positively correlated with the active political participation of women. As women who have educated husbands, get more political knowledge, exposure, and their participation in voting is ensured. 


\section{LIMITATIONS AND STUDY FORWARD}

For a study to be generalized for the whole province, a representative sample of 85 respondents is too less. We also acknowledge that the exclusion of widows and divorced women further limited the scope of the study. The study also did not consider the ethnic diversity of the rural Punjab where different families have different family cultures and may as a result vary in providing rights to women. A comprehensive study including all these dimensions will provide new insight into women empowerment in rural communities.

\section{AUTHORS CONTRIBUTIONS}

Abdullah Ijaz: The main researcher in formulation of the research design, data collection, basic layout of the research article.

Adnan Ahmad Dogar: The research lead in research design and overall supervision.

Ikram Shah, Mohammad Saeed Lodhi, and Shakirullah Dawar: Helped in the article write up, qualitative and quantitative analysis, and editing as per guidelines of the journal.

\section{REFERENCES}

1. Bandiera, O., Buehren, N., Burgess, R., Goldstein, M., Gulesci, S., Rasul, I., \& Sulaiman, M. J. A. E. J. A. E. (2020). Women's empowerment in action: evidence from a randomized control trial in Africa. American Economic Journal: Applied Economics, 12(1), 210-259. https://doi.org/10.1257/app.20170416

2. Bradshaw, S. (2013). Women's decision-making in rural and urban households in Nicaragua: the influence of income and ideology. Environment Urbanization, 25(1), 81-94. https://doi.org/10.1177/0956247813477361

3. Buvinic, M., O’Donnell, M., Knowles, J., \& Bourgault, S. (2020). Measuring women's economic empowerment. A compendium of selected tools. Center for Global Development.

4. Caldwell, J. C. (2007). Demographic Transition Theory. Springer. https://link.springer.com/book/10.1007\%2F9781-4020-4498-4

5. Center of Gender Policy Studies. (2016). Women's Economic Participation and Empowerment in Pakistan: Status Report 2016. UN Women Pakistan.

6. Chen, M., \& Mahmud, S. (1995). Assessing Change in Women's Lives: a Conceptual Framework. Bangladesh: BRAC-ICDDR,B Joint Research Project Dhaka.

7. Cornwall, A., \& Anyidoho, N. A. (2010). Introduction: Women's empowerment: Contentions and contestations. Development, 53(2), 144-149. https://doi.org/10.1057/dev.2010.34

8. Denney, J. M. (2015). Brief 11: Gender and the Sustainable Development Goals: Moving Beyond Women as a" Quick Fix" for Development. Boston: University of Massachusetts.

9. Dineen, K., \& Le, Q. V. (2015). The impact of an integrated microcredit program on the empowerment of women and gender equality in rural Vietnam. The Journal of Developing Areas, 49(1), 23-38. https://doi.org/10. 1353/jda.2015.0028

10. Duflo, E. (2012). Women Empowerment and Economic Development. Journal of Economic Literature, 50(4), 1051-1079. https://doi.org/10.1257/jel.50.4.1051

11. Friedman, J., \& Schady, N. (2009). How many more infants are likely to die in Africa as a result of the global financial crisis? World Bank Policy Research Working Paper(5023). https://doi.org/10.1596/1813-9450-5023

12. Furuta, M., \& Salway, S. (2006). Women's position within the household as a determinant of maternal health care use in Nepal. International family planning perspectives, 32(1), 17-27. https://doi.org/10.1363/3201706

13. Gupta, K., \& Yesudian, P. P. (2006). Evidence of women's empowerment in India: A study of socio-spatial disparities. GeoJournal, 65(4), 365-380. https://doi.org/10.1007/s10708-006-7556-Z

14. Hirji, F. (2021). Claiming our Space: Muslim Women, Activism, and Social Media. Islamophobia Studies Journal, 6(1), 78-92. https://doi.org/10.13169/islastudj.6.1.0078

15. James-Hawkins, L., Peters, C., VanderEnde, K., Bardin, L., \& Yount, K. M. (2018). Women's agency and its relationship to current contraceptive use in lower-and middle-income countries: A systematic review of the literature. Global Public Health, 13(7), 843-858. https://doi.org/10.1080/17441692.2016.1239270

16. Javed, S. A. (2021). Strategic Directions For Pakistan's Agenda For Smes. Sustainable Development Policy Institute. http://www.jstor.org/stable/resrep30581

17. Jayachandran, S. (2015). The roots of gender inequality in developing countries. The Annual Review of Economics, 7(1), 63-88. https://doi.org/10.1146/annurev-economics-080614-115404

18. Kabeer, N. (1999). Resources, agency, achievements: Reflections on the measurement of women's empowerment. Development Change, 30(3), 435-464. https://doi.org/10.1111/1467-7660.00125

19. Khan, R. E. A., \& Noreen, S. (2012). Microfinance and women empowerment: A case study of District Bahawalpur (Pakistan). African Journal of Business Management, 6(12), 4514-4521. https://doi.org/10.5897/AJBM11.2407 
20. Khan, U. M., Ijaz, R. H., \& Saadat, S. (2021). Extending Constitutional Rights to Pakistan's Tribal Areas. Washington DC: US Institute of Peace.

21. Lépine, A., \& Strobl, E. (2013). The effect of women's bargaining power on child nutrition in rural Senegal. World Development, 45, 17-30. https://doi.org/10.1016/j.worlddev.2012.12.018

22. Mahmud, S., Shah, N. M., \& Becker, S. (2012). Measurement of women's empowerment in rural Bangladesh. World Development, 40(3), 610-619. https://doi.org/10.1016/j.worlddev.2011.08.003

23. Malhotra, A., \& Schuler, S. R. (2005). Women's empowerment as a variable in international development. Measuring Empowerment: Cross-disciplinary Perspectives, 1(1), 71-88.

24. Malhotra, C., Malhotra, R., Østbye, T., \& Subramanian, S. (2014). Maternal autonomy and child health care utilization in India: results from the national family health survey. Asia Pacific Journal of Public Health, 26(4), 401-413. https://doi.org/10.1177/1010539511420418

25. Mustafa, G., Rizov, M., \& Kernohan, D. (2017). Growth, human development, and trade: The Asian experience. Economic Modelling, 61, 93-101. https://doi.org/10.1016/j.econmod.2016.12.007

26. O'Donnell, Buvinic. Mayra, Kenny. Charles, Bourgault. Shelby, \& George, Y. (2021). Promoting Women's Economic Empowerment in the COVID-19 Context. http://www.jstor.org/stable/resrep30886.7

27. Rehman, H., Moazzam, D. A., \& Ansari, N. (2020). Role of microfinance institutions in women empowerment: A case study of Akhuwat, Pakistan. South Asian Studies, 30(1), 107-125.

28. Roy, K., \& Tisdell, C. (2002). Property rights in women's empowerment in rural India: a review. International Journal of Social Economics, 29(4), 315-334. https://doi.org/10.1108/03068290210419870

29. Solomon, A. V., \& Adekoya, A. E. (2006). Women and Power Transformation in Rural Households: A Case Study of Osun State, Nigeria. The Social Sciences, 1(3), 231-234.

30. Stromquist, N. P. (2015). Women's E mpowerment and E ducation: linking knowledge to transformative action. European Journal of Education, 50(3), 307-324. https://doi.org/10.1111/ejed.12137

31. UN Women. (2018-2019). United Nations Entity for Gender Equality and the Empowerment of Women. 